\title{
High ecosystem multifunctionality under moderate grazing is associated with high plant but low bacterial diversity in a semi-arid steppe grassland
}

DOI:

10.1007/s11104-020-04430-6

\section{Document Version}

Accepted author manuscript

Link to publication record in Manchester Research Explorer

Citation for published version (APA):

Wang, X., Li, F. Y., Wang, Y., Liu, X., Cheng, J., Zhang, J., Baoyin, T., \& Bardgett, R. (2020). High ecosystem multifunctionality under moderate grazing is associated with high plant but low bacterial diversity in a semi-arid steppe grassland. Plant and Soil. https://doi.org/10.1007/s11104-020-04430-6

\section{Published in:}

Plant and Soil

\section{Citing this paper}

Please note that where the full-text provided on Manchester Research Explorer is the Author Accepted Manuscript or Proof version this may differ from the final Published version. If citing, it is advised that you check and use the publisher's definitive version.

\section{General rights}

Copyright and moral rights for the publications made accessible in the Research Explorer are retained by the authors and/or other copyright owners and it is a condition of accessing publications that users recognise and abide by the legal requirements associated with these rights.

\section{Takedown policy}

If you believe that this document breaches copyright please refer to the University of Manchester's Takedown Procedures [http://man.ac.uk/04Y6Bo] or contact uml.scholarlycommunications@manchester.ac.uk providing relevant details, so we can investigate your claim.

\section{OPEN ACCESS}




\section{High ecosystem multifunctionality under moderate grazing is} associated with high plant but low bacterial diversity in a semi-arid steppe grassland

Xinyu Wang ${ }^{1}$, Frank Yonghong $\mathrm{Li}^{1 *}$, Yanan Wang ${ }^{1}$, Xinmin Liu ${ }^{2}$, Jianwei Cheng ${ }^{1}$, Junzhen Zhang ${ }^{1}$, Taogetao Baoyin ${ }^{1}$, Richard D. Bardgett ${ }^{3}$

(1)

${ }^{1}$ Ministry of Education Key Laboratory of Ecology and Resource Use of the Mongolian Plateau \& Inner Mongolia Key Laboratory of Grassland Ecology, School of Ecology and Environment, Inner Mongolia University, Hohhot, 010021, China ${ }^{2}$ School of Life Science and Technology, Inner Mongolia Normal University, Hohhot, 010022, China

${ }^{3}$ School of Earth and Environmental Sciences, The University of Manchester, Oxford Road, Manchester, M13 9PT, UK

Author for correspondence: Frank Yonghong Li

Email: lifyhong@126.com Phone: 0086-471-4993130 or 0086-15848370560

Acknowledgements: The research was supported by the Ministry of Science and Technology of China (Grant No.2016YFC0500508; 2015BAC02B04; 2014CB138805) and the Department of Science and Technology of Inner Mongolia Autonomous Region of China (Grant for Key Basic Research on Grassland Ecosystems). RDB was supported by BBSRC GCRF grant (BB/P022987/1) "Restoring soil function and resilience to degraded grasslands". 


\section{Abstract}

Aims Current studies on the relationship between biodiversity and ecosystem functioning have mostly focused on plant communities. Less is known about the individual and combined effects of biodiversity components above-and-below-ground on ecosystem multifunctionality. The aim of this study was to explore how different management regimes influence multifunctionality via modification of both plant and soil microbial (bacterial and fungal) diversity.

Methods We used a 6-year experiment in Inner Mongolian grassland to compare multifunctionality and separate functions related to the $\mathrm{C}, \mathrm{N}, \mathrm{P}$ cycles and plant productivity under four management regimes and examine relationships between these functions and different components of biodiversity, both above- and belowground.

Results Ecosystem multifunctionality and the rates of nutrient cycling and plant productivity, were greatest under moderate grazing intensity, and lowest under no grazing. Further, across all management regimes, multifunctionality was positively related to plant diversity, and plant and soil microbial diversity combined explained a much greater $(62.5 \%)$ proportion of variance in multifunctionality than that did either component alone. Different components of biodiversity showed contrasting relationships with individual functions: plant diversity was positively related to $\mathrm{C}$ and $\mathrm{N}$ cycling, whereas bacterial diversity was negatively related to $\mathrm{P}$ cycling and plant productivity.

Conclusions Moderate grazing has better outcomes for biodiversity conservation and 
61

63

64

60 62

ecosystem multifunctionality than mowing and cessation of grazing. Sustainable grazing management is a viable strategy to conserve both above- and belowground biodiversity and enhance the delivery of multiple ecosystem functions.

\section{Keywords}

Aboveground biodiversity, belowground biodiversity, nutrient cycling, productivity, land management regimes, Inner Mongolian steppe

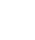
4

(1)

56

57
8

\section{9} 61

63

64




\section{Introduction}

Ecologists have long recognized that biodiversity can be the underpinning behind the performance of an ecosystem (Hector and Bagchi 2007; Zavaleta et al. 2010). The relationship between biodiversity and ecosystem functioning (hereafter BEF) was proposed by Darwin in 1859 (Hector and Hooper 2002), but it was only extensively explored in the past decades (Grime 1997; Naeem 2002). Most BEF studies indicate that species diversity enhances ecosystem functioning (Cardinale et al. 2012; Maestre et al. 2012), at least based on measures of single ecosystem functions, such as productivity, litter decomposition or soil nutrient cycling (Letts et al. 2015; Seidel et al. 2013). However, ecosystems are valued for multiple ecological functions that they provide simultaneously (i.e., multifunctionality) (Valencia et al. 2015; Zavaleta et al. 2010).

When the effects of biodiversity on ecosystem multifunctionality are examined, most attention is paid to the effects of aboveground plant diversity, while the effects of belowground biodiversity are less understood (Bradford et al. 2014; Delgado-Baquerizo et al. 2017). Soil is highly diverse, with literally billions of organisms and tens of thousands of microbial taxa within a single habitat (Roesch et al. 2007). This immense soil biodiversity plays critical roles in a wide range of ecosystem functions, such as plant production, litter decomposition, organic matter mineralization, and nutrient cycling (Bardgett and van der Putten 2014; de Vries et al. 2013; Wardle et al. 2004). Recent studies have increasingly examined the relationships between soil microbial biodiversity and ecosystem multifunctionality 
(Delgado-Baquerizo et al. 2016; Jing et al. 2015; Wagg et al. 2014); however, it remains unclear how soil microbial diversity, in combination with the aboveground plant diversity, affects ecosystem multifunctionality under different land uses (Allan et al. 2015; Delgado-Baquerizo et al. 2016).

Land use change due to the increasing anthropogenic activities is the most important driver leading to biodiversity loss (Pereira et al. 2012) and alteration of multiple ecosystem functions (Allan et al. 2015; Chillo et al. 2016). The effects of land use change on ecosystem processes can be direct via the alteration of soil physicochemical properties (Walter et al. 2013) or indirect via the alteration of plant and soil community structure and diversity (Mayfield et al. 2010; Yang et al. 2013). Grazing, mowing (for hay), and enclosure to exclude livestock completely, are the three most common management regimes on steppe grassland in Inner Mongolia, and in many other grassland regions of the world (Baoyin et al. 2014; Li et al. 2008). Grazing alters the composition of plant communities and resource availability through a variety of mechanisms, including selective defoliation, trampling, and deposition of animal wastes (Bardgett and Wardle 2003). Moderate grazing means a proper grazing intensity that maintains a dynamic balance between grazing quantity and carrying capacity of grassland. The key is that herbivores can evoke plant growth compensation mechanisms and promote primary production (de Mazancourt et al. 1999; Hayashi et al. 2007). Many studies have found that moderate grazing reduces plant interspecific competition and may enhance plant species diversity, further improve nutrient cycling and plant growth (Carrera et al. 2008; Zou et al. 2015). 
Mowing affects biological communities and ecosystem functions primarily through non-selective plant biomass removal (Catorci et al. 2014), which may enhance the compensatory growth of plant species and the mineralization of soil nutrients (Wan et al. 2016). Enclosure by fencing is now widely used in Inner Mongolia for the restoration of degraded grasslands. It may cause major shifts in vegetation composition, changes in soil resource availability, and affect belowground decomposer organisms, ultimately affecting ecosystem functions (Bardgett and Wardle 2003). Therefore, it is imperative to understand the impact of the changes in biodiversity, both above- and belowground, on ecosystem multifunctionality under different land management regimes within heterogeneous environments in the field.

Here, we used a 6-year experiment in Inner Mongolia to examine relationships among different components of biodiversity, both above- and belowground, individual ecosystem functions of $\mathrm{C}, \mathrm{N}$, and $\mathrm{P}$ cycling and plant productivity, and ecosystem multifunctionality of typical steppe grassland subject to different management regimes. Our aim was to explore how different management regimes influence ecosystem multifunctionality via modification of both plant and soil microbial diversity. We hypothesized that (i) the moderately grazed grassland has the highest ecosystem multifunctionality, or separate ecosystem functions of nutrient cycling and productivity, whereas the enclosed grassland has the lowest; (ii) the changes in ecosystem multifunctionality across different land management regimes can be predicted by the responses of different components of biodiversity, including plant diversity and soil (bacterial and fungal) diversity to management; and (iii) the above- 
and belowground biodiversity combined is a stronger predictor of ecosystem multifunctionality than either above- or belowground biodiversity alone.

\section{Methods and materials}

\section{Study site and experimental design}

This study was conducted at the Grassland Ecosystem Research Station of Inner Mongolia University, located in the Xilingol region of Inner Mongolia, China ( $44^{\circ} 10^{\prime}$ N, $116^{\circ} 28^{\prime}$ E, $1101 \mathrm{~m}$ asl) (See Fig. S3a for location of the study site). The region experiences a temperate semi-arid climate. Mean annual temperature is $-0.5{ }^{\circ} \mathrm{C}$, with the lowest monthly mean temperature in January $\left(-19.6^{\circ} \mathrm{C}\right)$ and the highest in July $\left(21.8{ }^{\circ} \mathrm{C}\right)$. Mean annual precipitation is $315 \mathrm{~mm}$; the precipitation has a wide inter-annual fluctuation, and $80 \%$ of which falls between May and September (climatic data from the Xilinhot meteorological station). The natural vegetation is a typical steppe dominated by Leymus chinensis (Trin.) Tzvel., Stipa krylovii Roshev and Cleistogenes squarrosa (Trin.) Keng.. The soil is a sandy loam chestnut soil (or Calcic-orthic Aridisol in the US soil taxonomy classification system) with mean $\mathrm{pH}$ of 8.07 in plant root layer $(0-20 \mathrm{~cm})$.

The experiment was established in 2011 to investigate the effects of different management regimes on grassland ecosystems. The land use treatments considered in this study were: all growing-season grazing with sheep grazing once every calendar month from May to September, starting on the 20th of each month, and ending when grassland residual height reached to $6 \mathrm{~cm}(\mathrm{G} 1)$; spring \& summer grazing with sheep 
153

grazing twice each year (in May and July), also starting on the 20th of each month and ending when grassland residual height reached to $6 \mathrm{~cm}(\mathrm{G} 2) ;$; mowing to $6 \mathrm{~cm}$ once a year on the 20th August, with the mown herbage removed for hay-making (M); the $6 \mathrm{~cm}$ stubble height was consistently considered to be a reasonable height for sustainable use of the studied grassland (Baoyin et al. 2014); and enclosure by wire fence, no grazing or mowing since 2011 (E). The four treatments were assigned in a randomized block design replicated three times. The size of each replicated plot was $1100 \mathrm{~m}^{2}\left(1 / 9 \mathrm{hm}^{2}=33.3 \mathrm{~m} \times 33.3 \mathrm{~m}\right)$ (See Fig. S3b for layout of the experimental plots). For grazing treatments (G1 and G2), the experimental sheep species was Ujimqin sheep, and a flock of six sheep was used in each plot. Thus the grazing intensity in G1 and G2 were similar and moderate due to the same grazing quantity and relatively high residual height, but the frequent gazing in G1 might have greater effects on grasslands than G2. In 2017 , four $1 \mathrm{~m} \times 1 \mathrm{~m}$ cages were set up in each grazing plot (G1 and G2) before the grazing season, so as to evaluate the diversity of plant community in the peak season of plant growth (August).

\section{Plant sampling and analysis}

We sampled plant and soil communities in the plots under the four land use treatments in mid-August 2017. Within each of the 12 plots (four treatments $\times$ three replicates), we surveyed plant communities using four $1 \mathrm{~m} \times 1 \mathrm{~m}$ quadrats in each plot, to record species richness and abundance, and harvest plant aboveground biomass by species and weigh after $48 \mathrm{~h}$ oven-drying at $65^{\circ} \mathrm{C}$. Aboveground dry material was 
then ground to a fine powder, and used to determine plant nitrogen content using an elemental analyzer (Vario EL III, Elementar, Hanau, Germany), and determine plant phosphorus content using the Mo-Sb colorimetric method with a visible-wavelength spectrophotometer (V-722, Jinghua, Shanghai, China).

The total aboveground biomass of the mowing or enclosing grasslands at peak plant growing season was used as a proxy of aboveground productivity. While for grazing grasslands (G1 and $\mathrm{G} 2)$, two cages $(1 \mathrm{~m} \times 1 \mathrm{~m})$ were set up before each grazing in each plot, and the difference between the biomass inside and outside of each cage was used to estimate the sheep feed intake during each grazing rotation. Thus the aboveground productivity of grazing grasslands was calculated as the sum of feed intake during the season and the residual biomass at the end of last grazing in the season. We also estimated plant root biomass by collecting three soil cores from each of four quadrats in each plot, which were used to generate a composite sample (0-30 $\mathrm{cm}$ depth, $7 \mathrm{~cm}$ diameter) as a proxy of belowground productivity. Roots were collected by rinsing the samples using sieves (mesh size $0.25 \mathrm{~mm}$ ) on the same day, and then oven dried at $65^{\circ} \mathrm{C}$ for $48 \mathrm{~h}$ and weighed.

\section{Soil sampling and analysis}

After removal of plant material in the four quadrats in each plot, four soil cores (0-20 cm depth, $5 \mathrm{~cm}$ diameter) were collected from the quadrats, which were bulked to produce a composite sample. Each fresh soil sample was sieved through a $2 \mathrm{~mm}$ mesh to remove visible roots and stones, and then divided into three subsamples. Two 
of the three subsamples were immediately kept on ice, transported back to the laboratory and stored at $-20{ }^{\circ} \mathrm{C}$ for microbial DNA extraction and $-4{ }^{\circ} \mathrm{C}$ for soil available nitrogen analysis respectively, while the other was air-dried for analysis of other soil properties.

Soil physiochemical analysis

Excess hydrochloric acid was added firstly to decompose the inorganic carbonate into carbon dioxide to remove the interference of inorganic carbon on measurement results (Harris et al. 2001), then total organic carbon (TOC) was determined by a liquiTOC analyzer (Elementar, Hanau, Germany). Total nitrogen (TN) was determined by a Vario MACRO cube elemental analyzer (Elementar, Hanau, Germany). Soil inorganic nitrogen ( $\mathrm{AN}: \mathrm{NH}_{4}{ }^{+}$and $\mathrm{NO}_{3}{ }^{-}$) was measured using a $\mathrm{KCL}$ extraction procedure, and analyzed on a Flow analyzer (AA3, SEAL Analytical, Germany). Soil available phosphorus (Olsen-p; AvP) was measured by the Mo-Sb colorimetric method with a visible-wavelength spectrophotometer (V-722, Jinghua, Shanghai, China). The activities of urease (S-UE) and alkaline phosphatase (S-AKP) were determined by the indophenol blue colorimetric method and phenyl disodium phosphate colorimetric method respectively using the soil enzyme assay kits (Keming biotechnology, Suzhou, China). The basic principle for S-UE measurement is that S-UE hydrolyzes urea to produce $\mathrm{NH}_{4}{ }^{+}-\mathrm{N}$, which reacts with hypochlorite and phenol in a strong alkaline medium to form water-soluble indophenol blue; the basic principle for S-AKP measurement is that S-AKP catalyzes the hydrolysis of phenyl disodium phosphate to phenol, which reacts with chlorobromobenzoquinone imine for 
further color development. We then determined their absorbance at $578 \mathrm{~nm}$ and 660 nm, respectively, through a Multi-function microplate reader (Epoch, BioTek,

221 Vermont, USA). Measurements of greenhouse gases $\left(\mathrm{CO}_{2}\right.$ and $\left.\mathrm{CH}_{4}\right)$ were conducted 222 using enclosed static chamber method through a high-performance gas chromatography equipped with hydrogen flame ionization detector (FID) (7890A, Agilent Technologies, California, USA). Gas samples were collected every two hours (from 6:00am to 24:00pm) at 7-day intervals during the 2017 growing season (May-September). The average gas fluxes at three measurements in August were used in analysis, in consistent with sampling period of plants and soil microbes (See more details in Online Resource 1).

Soil microbial DNA extraction and determination for soil (MP Biomedical, Carlsbad, CA, USA). To investigate the taxonomic composition of soil bacterial and fungal communities, operational taxonomic units (OTUs) were classified at the phylum and class levels. To assess bacterial communities, the V3-V4 hypervariable regions of bacterial 16S rRNA were amplified using the primer set: 341F (5'-ACTCCTACGGGAGGCAGCAG-3'), 806R (5'-GGACTACHVGGGTWTCTAAT-3'). To assess fungal communities, the second 237 internal transcribed spacer region (ITS2) gene fragment was amplified using the primer $\quad$ set: $\quad$ its3 (5'-GCATCGATGAAGAACGCAGC-3'), its4 (5'-TCCTCCGCTTATTGATATGC-3'). The high-throughput sequencing of the 12 soil microbial total DNA was done by Wuhan Biotechnology BGI Co., Ltd., Wuhan, 
China (See more details in Online Resource 1).

\section{Assessing biodiversity and multifunctionality}

We calculated Shannon-Weiner index to assess the diversity of plant and soil microbial communities, and chose 12 ecosystem functional variables to assess multifunctionality. These 12 functional variables were related to the cycling of carbon (TOC, $\mathrm{CO}_{2}$ fluxes, and $\mathrm{CH}_{4}$ fluxes), nitrogen (TN, AN, S-UE, and plant nitrogen content), phosphorus (AvP, S-AKP, and plant phosphorus content) and biological productivity (plant aboveground biomass and root biomass). These variables constitute good proxies of processes driving nutrient cycling, primary production and the build-up of nutrient pools (Delgado-Baquerizo et al. 2017; Manning et al. 2018). Various methods have been proposed to quantify the multiple functions of ecosystems (Byrnes et al. 2014; Manning et al. 2018), and the multifunctionality index (M-index) (Maestre et al. 2012) is the one of them. The index provides a straightforward, easily interpretable measure of a community's ability to sustain multiple functions simultaneously (Byrnes et al. 2014). It also has good statistical properties (Maestre et al. 2012) and has been increasingly used in the literature (Bradford et al. 2014; Valencia et al. 2015). Moreover, in our case, the correlations between the variables show a low redundancy within the data, and M-index is well correlated with other previously proposed multifunctionality indices (Online Resource 1: Figs. S1-2). Thus, we calculated Z-scores of these 12 variables and averaged them to obtain multifunctionality (M-index) in each plot, following the approach of Maestre et al. (2012). In the 12 functions chosen, we identified these functions for which lower values indicate higher functioning, and multiplied them by -1 to reflect their negative relations with the strength of ecosystem functioning; these variables included soil 
inorganic $\mathrm{N}$ and soil available $\mathrm{P}$, as well as $\mathrm{CO}_{2}$ fluxes. A 5-year grazing experimental study showed that the net $\mathrm{N}$ mineralization rate and cumulative $\mathrm{N}$ mineralization were significantly lower under moderate grazing intensity than under no grazing in the peak plant growing season in the steppe grassland in the Xilingol region of Inner Mongolia (Shan et al. 2011); thus the lower inorganic $\mathrm{N}$ content and soil available P content in August in the studied grassland were deemed the results of greater capture or utilization of these soil nutrients by plants (Scherer-Lorenzen et al. 2003). The lower values of $\mathrm{CO}_{2}$ fluxes represented less greenhouse gas emission. The value of $\mathrm{CH}_{4}$ fluxes was not multiplied by -1 as the steppe grassland is a $\mathrm{CH}_{4}$ sink. We also added the unreflected maximum to each of the three functions so that the lowest value of each transformed function was 0 (Byrnes et al. 2014). Additionally, we calculated the C-cycling index, N-cycling index, P-cycling index and productivity index separately based on the different groups of variables specified in the parentheses above (See more details in Online Resource 1).

\section{Statistical analyses}

Data on P-cycling index was sine transformed to meet the normality assumption and homogeneity of variance. We first conducted one-way analyses of variance (ANOVA) to compare the differences of M-index and separate functions related to the $\mathrm{C}, \mathrm{N}, \mathrm{P}$ cycles and plant productivity among grazing, mowing and enclosure treatments using Least-significant difference (LSD) tests for post hoc comparisons at $P<0.05$. Then, we analysed the community composition of plants and soil microbes and compared the differences of dominant species or classes among treatments (LSD tests at $P<0.05$ ). We also examined the relationships of biodiversity with $\mathrm{M}$-index, 
and with its component functions linked to the C, N, P cycles and plant productivity using general linear models (GLMs). In order to evaluate the combined effects of plant and soil microbial biodiversity on M-index after the effects of management treatments across plots and blocks were excluded, we fitted the linear mixed-effects models, with biodiversity as a fixed effect, and land use treatment and block as two random effects. Marginal $R^{2}$ is reported as a measure of the explanatory power of biodiversity (Nakagawa and Schielzeth 2013). We also computed the variance inflation factor (VIF) among the explanatory variables to check their multicollinearity. The VIF was in all cases below two, suggesting the absence of collinearity problems. The ANOVA were conducted in SPSS software version 19.0. The remaining statistical analyses were performed with R version 3.3.1 (R Core Development Team, 2013).

\section{Results}

\section{Grassland management and ecosystem multifunctionality}

The M-index was significantly higher under grazing (both G1 and G2) and mowing than in ungrazed enclosure, and was significantly higher under G2 than mowing (Fig. 1). (The details of each component of M-index across the treatments were given in Online Resource 1: Fig. S4). In terms of individual components of the M-index, the C-cycling, P-cycling, and productivity indices were all significantly higher under grazing (both G1 and G2) than in enclosure, whereas the N-cycling index was significantly higher only in G1, but not in G2, than in enclosure (Fig. 2). In general, grazed grassland had the highest functional values, while ungrazed, enclosed 
grassland had the lowest.

\section{Taxonomic composition of plant and soil microbial communities and} relationships between biodiversity and ecosystem multifunctionality

Plant community was dominated by L. chinensis, S. krylovii and C. squarrosa, which accounted for $11.7 \%-78.2 \%, 0.4 \%-52.0 \%$, and $4.6 \%-37.1 \%$ of the total aboveground biomass, respectively. After the 6-year land management treatments, the relative abundance of $S$. krylovii was significantly higher, whereas that of $L$. chinensis was significantly lower, in grazing (both G1 and G2) and mowing than no-grazing grasslands; the relative abundance of $C$. squarrosa was significantly higher in all growing-season grazing (G1) than no-grazing grasslands; the relative abundance of $S$. krylovii was also significantly higher, whereas that of L. chinensis was significantly lower, in G1 than mowing grasslands, and the relative abundance of L. chinensis was significantly lower under G1 than G2 (Fig. S5a).

Thirty-five phyla and 37 classes were identified in soil bacterial community. A majority of the bacterial $16 \mathrm{~S}$ rRNA gene sequences were associated with the Actinobacteria, Acidobacteria and Proteobacteria phyla, which represented $26.6 \%-37.3 \%, 19.0 \%-30.7 \%$ and $12.7 \%-16.5 \%$ of the total sequences, respectively. The remaining phyla (inclusive of 'unclassified') accounted for $26.3 \%-30.5 \%$ of the communities overall. At the class level, the community was dominated by Chloracidobacteria (10.5\%-21.6\%), Thermoleophilia (10.3\%-16.5\%), Acidimicrobiia $(4.3 \%-8.3 \%)$, Alphaproteobacteria $(5.5 \%-7.9 \%)$, and Actinobacteria $(4.9 \%-7.1 \%)$. 
The relative abundance of Acidimicrobiia was significantly lower under G2 than G1, and the relative abundance of Actinobacteria was significantly lower in G2 than in other three treatments; no significant differences were detected in the relative abundance of remaining three classes among management types (Fig. S5b). Five phyla were identified in soil fungal community, including Ascomycota, Basidiomycota, Chytridiomycota, Glomeromycota, and Zygomycota. The dominant phyla were Basidiomycota, Ascomycota and Zygomycota, which represented $22.8 \%-81.1 \%, 11.0 \%-59.2 \%$, and $3.0 \%-27.0 \%$ of the total sequences, respectively. The remaining two phyla (inclusive of 'unclassified') accounted for only $4.9 \%-17.5 \%$ of the overall. At the class level, OTUs comprised 11 fungal classes, with the predominantly abundant corresponding to Agaricomycetes (20.9\%-80.3\%), Incertae_sedis $(3.3 \%-27.5 \%)$, Sordariomycetes $(3.5 \%-18.1 \%)$, Eurotiomycetes $(0.8 \%-16.0 \%)$, and Dothideomycetes $(2.5 \%-11.9 \%)$. The relative abundance of Eurotiomycetes was significantly lower in enclosure than in other three treatments; no significant differences were detected in the relative abundance of remaining four classes among management types (Fig. S5c).

The relationships between biodiversity and multifunctionality varied among different components of above- and belowground diversity. Multifunctionality was positively related with plant diversity, but negatively related with bacterial diversity, and was not related with fungal diversity (Fig. 3). For fungal diversity, we removed one outlier point from the fitted relationship and completed the analyses using the remaining points (See Fig. S6 for more details). Plant diversity was positively related 
with $\mathrm{C}$ and $\mathrm{N}$ cycling indices (Fig. 4a, b), while bacterial diversity was negatively related with $\mathrm{P}$ cycling index and productivity index (Fig. $4 \mathrm{~g}, \mathrm{~h}$ ). No significant relations were detected between other biodiversity components and functional index pairs (Fig. 4c-f), including between soil fungal diversity and any of these indices (data not shown on Fig. 4).

\section{Combined and separate effects of above- and belowground biodiversity on} multifunctionality

The combined effects of above- and belowground biodiversity on multifunctionality were examined using linear mixed-effects models. We found that $62.5 \%$ of variation in multifunctionality was accounted for by plant and soil microbial biodiversity combined, after the effects of land-use treatments and blocks were both excluded (Table 1). The variation in multifunctionality explained jointly by the plant and soil microbial diversity was much greater than the sum of the variation explained separately by plant $(40.2 \%)$, bacterial $(7.6 \%)$, and fungal diversity $(0.4 \%)$. As such, above- and belowground biodiversity combined is a better predictor of ecosystem multifunctionality.

\section{Discussion}

\section{Multifunctionality and individual ecosystem functions under different} management regimes

Grazing, mowing and enclosure are three of the main management regimes in 
grassland regions. Using the typical steppe grassland in Inner Mongolia as a model, we tested for relationships between ecosystem multifunctionality and different components of biodiversity across grassland sites subjected to different long-term management regimes. Our results show that grazing (G1 \& G2) and mowing (M) significantly enhance ecosystem multifunctionality relative to enclosure (E). We also show that the enhancement of multifunctionality under less frequent grazing (G2) is significantly greater than for mowing (Fig. 1). Many studies have demonstrated that moderate grazing may improve nutrient cycling and soil carbon storage, and induce compensatory plant growth (Carrera et al. 2008), which are deemed to be primary mechanisms responsible for positive effects of moderate grazing on grassland production, or the grazing optimization hypothesis (Hayashi et al. 2007). As such, our results obtained in this study are consistent with those described for grassland under moderate grazing, and the high M-index under grazing is mainly attributed to high nutrient cycling and productivity (Fig. 2). The variation of 12 variables across different management regimes also shows that grazing grasslands have low $\mathrm{CO}_{2}$ emissions (G1), low soil available P content and high belowground plant biomass (G2) (Online Resource 1: Fig. S4).

Mowing increases the $\mathrm{N}$ content in plant leaves, thus decreasing the $\mathrm{C}$ : $\mathrm{N}$ ratio and lignin: $\mathrm{N}$ ratio in plant litter, which in turn stimulates soil microbial activity, thereby accelerating rates of litter decomposition and nutrient cycling (Walter et al. 2013). At the same time, mowing and associated herbage removal reduce plant litter accumulation, which can benefit the growth of some aerobic bacteria and promote 
nutrients transformations in soil (Raich and Schlesinger 1992). Further, previous studies on the steppe grassland in Inner Mongolia indicate that mowing once a year causes compensatory plant growth, which is associated with enhanced availability of soil $\mathrm{N}$ and $\mathrm{P}$ (Baoyin et al. 2014). Thus, our results show that mowed grassland (M) has a significantly greater $\mathrm{M}$-index than ungrazed grassland $(\mathrm{E})$, indicating that mowing enhances ecosystem multifunctionality. However, the enhancement of nutrient cycling by mowing for hay is much smaller than that by animal grazing (Kohler et al. 2005), which in this study resulted in a lower C cycling index under mowing than all growing-season grazing (G1) and lower P cycling and productivity indices and overall M-index under mowing than spring \& summer grazing (G2) (Figs. $1-2)$.

It is commonly believed that cessation of grazing has short-term benefits for 411 vegetation and soil functioning (Bai et al. 2007), but long-term enclosure is detrimental to the stability of steppe ecosystem and the comprehensive utilization of energy (Wan et al. 2016). Ungrazed grasslands have no biomass removal, and thus accumulate large amounts of recalcitrant organic matter in the litter layer, which reduces rates of decomposition and nutrient cycling (Hossain and Sugiyama 2010).

416 Consistent with this, indices of $\mathrm{C}, \mathrm{N}$ and $\mathrm{P}$ cycling and productivity were lower in 417 ungrazed than in grazed grasslands (Fig. 2). These results are not surprising as the C, $418 \quad \mathrm{~N}$ and $\mathrm{P}$ cycling processes are coupled. 


\section{multifunctionality}

422

423

It is now widely accepted that plant diversity is a key driver of ecosystem functioning in a wide range of ecosystems (Cardinale et al. 2012; Zavaleta et al. 2010), and recent studies also show that plant diversity tends to be positively related with ecosystem multifunctionality (Maestre et al. 2012; Pasari et al. 2013). Our results are consistent with this, showing that plant diversity and multifunctionality are positively related across a range of grassland management regimes (Fig 3). Furthermore, we also show that the diversity of soil microorganism is related to ecosystem multifunctionality, and that combined, plant and soil microbial diversity explain a much greater $(62.5 \%)$ proportion of variance in multifunctionality than that does either component alone (Table 1). As such, our results demonstrate that incorporating both above- and belowground biodiversity significantly enhances the predictability of biodiversity effects on ecosystem multifunctionality.

We also find plant diversity to be related with $\mathrm{C}$ and $\mathrm{N}$ cycling indices in our study site (Fig. 4a-b), suggesting that plant diversity is particularly vital to maintain ecosystem functions linked to $\mathrm{C}$ and $\mathrm{N}$ cycling, and subsequently to sustain $\mathrm{C}$ sequestration and soil fertility (Maestre et al. 2012; Reid et al. 2005). Soil microorganisms can indirectly influence ecosystem functions, such as plant productivity, via the actions that alter rates of nutrient supply and resource partitioning. These effects can either stimulate ecosystem functions, through enhancing nutrient availability for plant uptake, or reduce the functions through competing for nutrients with plant root and/or promoting nutrient loss via leaching of 

444 show that soil bacterial diversity was significantly and negatively related with 445 ecosystem multifunctionality, and with $\mathrm{P}$ cycling index and plant productivity, across

mobile nutrient forms (van der Heijden et al. 2008; Wardle et al. 2004). Our results the different management regimes (Fig. 3, Fig. 4g-h). Previous studies have shown that effects of soil bacterial diversity on plant productivity can range from positive to negative depending on context, spatial and temporal scale, and site fertility (Mittelbach et al. 2001; Wardle et al. 2004), and the negative effects might be attributed to competition of bacteria and plants for limiting nutrients, especially in $\mathrm{N}$ and P limited ecosystems, such as arctic tundra (Nordin et al. 2004), temperate forest (Finzi and Berthrong 2005), and low productivity grassland (Bardgett et al. 2003). While caution is needed in the interpretation of relationships, we speculate that the negative relationships between bacterial diversity and $\mathrm{P}$ cycling and plant productivity found in our study is due to competition for nutrients under the low-nutrient conditions in the studied grassland, which reduces $\mathrm{P}$ availability for plants and inevitably limits primary productivity (Bell et al. 2013). This speculation is also supported by the evidence provided by (Schmidt et al. 1997) that soil sterilization increases plant $\mathrm{N}$ and $\mathrm{P}$ uptake and growth, and suggests that microbes can compete effectively with plants for nutrient, thereby limiting plant growth. This, however, requires further testing to identify the mechanisms involved in our situation.

It is well known that fungi play important roles in regulating energy and nutrient fluxes through their hypha structures (Cairney 2005; Dighton 2007; Holden et al. 2013). However, no significant effect of fungal diversity on ecosystem 
multifunctionality is detected across the management regimes in our study (one outlier point was removed) (Fig 3), and the variation in fungal diversity is very small (Table S1) whereas that in multifunctionality is large across the management regimes. Further studies with increased sample size over multiple years are warranted to explore the relation between fungal diversity and ecosystem multifunctionality.

\section{Conclusion}

Our results demonstrate that the grasslands under moderate grazing perform best in terms of sustaining a high multifunctionality, including enhanced nutrient cycling and plant productivity. Further, we find that the removal of grazing, which is commonly proposed to be a means of restoring degraded grassland, is the least effective management for enhancing biodiversity and multifunctionality. As such, we suggest moderate grazing as the most effective management for maintaining biodiversity and preserving ecosystem functioning in steppe grassland. We also show that the effects of grassland management on ecosystem multifunctionality can be explained by contrasting responses of different components of biodiversity, namely plant, bacterial, and fungal diversity, but that above- and belowground biodiversity combined is a more effective predictor of ecosystem multifunctionality than any component alone. Accordingly, our findings suggest that it is essential to incorporate both the above- and belowground biodiversity in assessing the multifunctionality for conservation and sustainable management of grassland ecosystems. 


\section{References}

488

Allan E, Manning P, Alt F, Binkenstein J, Blaser S, Blüthgen N, Böhm S, Grassein F, Hölzel N, Klaus VH (2015) Land use intensification alters ecosystem multifunctionality via loss of biodiversity and changes to functional composition. Ecol Lett 18:834-843

Bai Y, Wu J, Pan Q, Huang J, Wang Q, Fusheng LI, Alexander B, Han X (2007) Positive linear relationship between productivity and diversity: evidence from the Eurasian steppe. J Appl Ecol 44:1023-1034

Baoyin T, Li FY, Bao Q, Minggagud H, Zhong Y (2014) Effects of mowing regimes and climate variability on hay production of Leymus chinensis (Trin.) Tzvelev grassland in northern China. The Rangeland Journal 36:593-600 doi:10.1071/rj13088

Bardgett RD, Streeter TC, Bol R (2003) Soil microbes compete effectively with plants for organic-nitrogen inputs to temperate grasslands. Ecology 84:1277-1287

Bardgett RD, van der Putten WH (2014) Belowground biodiversity and ecosystem functioning. Nature 515:505-511 doi:10.1038/nature13855

Bardgett RD, Wardle DA (2003) Herbivore-mediated linkages between aboveground and belowground communities. Ecology 84:2258-2268

Bell TH, Callender KL, Whyte LG, Greer CW (2013) Microbial competition in polar soils: a review of an understudied but potentially important control on productivity. Biology 2:533-554

Bradford MA, Wood SA, Bardgett RD, Black HI, Bonkowski M, Eggers T, Grayston SJ, Kandeler E, Manning $P$, Setälä $H$ (2014) Discontinuity in the responses of ecosystem processes and multifunctionality to altered soil community composition. Proc Natl Acad Sci U S A 111:14478-14483

Byrnes JEK, Gamfeldt L, Isbell F, Lefcheck JS, Griffin JN, Hector A, Cardinale BJ, Hooper DU, Dee LE, Duffy JE (2014) Investigating the relationship between biodiversity and ecosystem multifunctionality: challenges and solutions. Methods Ecol Evol 5:111-124

Cairney JWG (2005) Basidiomycetes mycelia in forest soils: dimensions, dynamics and roles in nutrient distribution. Mycol Res 109:7-20

Cardinale BJ, Duffy JE, Gonzalez A, Hooper DU, Perrings C, Venail P, Narwani A, Mace GM, Tilman D, Wardle DA, Kinzig AP, Daily GC, Loreau M, Grace JB, Larigauderie A, Srivastava DS, Naeem S (2012) Biodiversity loss and its impact on humanity. Nature 486:59-67 doi:10.1038/nature11148

Carrera AL, Bertiller MB, Larreguy C (2008) Leaf litterfall, fine-root production, and decomposition in shrublands with different canopy structure induced by grazing in the Patagonian Monte, Argentina. Plant Soil 311:39-50

Catorci A, Cesaretti S, Malatesta L, Tardella FM (2014) Effects of grazing vs mowing on the functional diversity of sub-Mediterranean productive grasslands. Appl Veg Sci 17:658-669

Chillo V, Ojeda RA, Capmourteres V, Anand M (2016) Functional diversity loss with increasing livestock grazing intensity in drylands: the mechanisms and their consequences depend on the taxa. J Appl Ecol 54:986-996

de Mazancourt C, Loreau M, Abbadie L (1999) Grazing optimization and nutrient cycling: potential impact of large herbivores in a savanna system. Ecological Applications 9:784-797 
de Vries FT, Thébault E, Liiri M, Birkhofer K, Tsiafouli MA, Bjørnlund L, Jørgensen HB, Brady MV, Christensen S, de Ruiter PC, Bardgett RD (2013) Soil food web properties explain ecosystem services across European land use systems. Proc Natl Acad Sci USA 110:14296-14301

Delgado-Baquerizo M, Eldridge DJ, Ochoa V, Gozalo B, Singh BK, Maestre FT (2017) Soil microbial communities drive the resistance of ecosystem multifunctionality to global change in drylands across the globe. Ecol Lett 20:1295-1305

Delgado-Baquerizo M, Maestre FT, Reich PB, Jeffries TC, Gaitan JJ, Daniel E, Miguel B, Campbell CD, Singh BK (2016) Microbial diversity drives multifunctionality in terrestrial ecosystems. Nat Commun 7:1-8

Dighton J (2007) Nutrient cycling by saprotrophic fungi in terrestrial habitats. In: Kubicek CP, Druzhinina IS (eds) The Mycota IV environmental and microbial relationships. Springer Berlin Heidelberg, New York, NY, pp 287-300

Finzi AC, Berthrong ST (2005) The uptake of amino acids by microbes and trees in three cold-temperate forests. Ecology 86:3345-3353

Grime JP (1997) Biodiversity and ecosystem function: the debate deepens. Science 277:1260-1261

Harris D, Horwáth WR, Kessel CV (2001) Acid Fumigation of Soils to Remove Carbonates Prior to Total Organic Carbon or Carbon-13 Isotopic Analysis. Soil Sci Soc Am J 65:1853-1856

Hayashi M, Fujita N, Yamauchi A (2007) Theory of grazing optimization in which herbivory improves photosynthetic ability. J Theor Biol 248:367-376

Hector A, Bagchi R (2007) Biodiversity and ecosystem multifunctionality. Nature 448:188-190

Hector A, Hooper R (2002) Darwin and the first ecological experiment. Science 295:639-640

Holden SR, Gutierrez A, Treseder KK (2013) Changes in soil fungal communities, extracellular enzyme activities, and litter decomposition across a fire chronosequence in Alaskan boreal forests. Ecosystems 16:34-46

Hossain MZ, Sugiyama SI (2010) Effects of chemical composition on the rate and temporal pattern of decomposition in grassland species leaf litter. Grassl Sci 54:40-44

Jing X, Sanders NJ, Shi Y, Chu H, Classen AT, Zhao K, Chen L, Shi Y, Jiang Y, He JS (2015) The links between ecosystem multifunctionality and above- and belowground biodiversity are mediated by climate. Nat Commun 6:8159-8166

Kohler F, Hamelin J, Gillet F, Gobat JM, Buttler A (2005) Soil microbial community changes in wooded mountain pastures due to simulated effects of cattle grazing. Plant Soil 278:327-340

Letts B, Lamb EG, Mischkolz JM, Romo JT (2015) Litter accumulation drives grassland plant community composition and functional diversity via leaf traits. Plant Ecol 216:357-370

Li Y, Wang W, Liu Z, Jiang S (2008) Grazing gradient versus restoration succession of Leymus chinensis (Trin.) Tzvel. Grassland in Inner Mongolia. Restor Ecol 16:572-583

Maestre FT, Quero JL, Gotelli NJ, Escudero A, Ochoa V, Delgado-Baquerizo M, García-Gómez M, Bowker MA, Soliveres S, Escolar C, Zaady E (2012) Plant species richness and ecosystem multifunctionality in global drylands. Science 335:214-218

Manning P, van der Plas F, Soliveres S, Allan E, Maestre FT, Mace G, Whittingham MJ, Fischer M (2018) Redefining ecosystem multifunctionality. Nat Ecol Evol 2:427-436 doi:10.1038/s41559-017-0461-7

Mayfield MM, Bonser SP, Morgan JW, Aubin I, Mcnamara S, Vesk PA (2010) What does species richness tell us about functional trait diversity? Predictions and evidence for responses of species and functional trait diversity to land-use change. Global Ecol Biogeogr 19:423-431 
Mittelbach GG, Steiner CF, Scheiner SM, Gross KL, Reynolds HL, Waide RB, Willig MR, Dodson SI, Gough $L$ (2001) What Is the observed relationship between species richness and productivity? Ecology 82:2381-2396

Naeem S (2002) Ecosystem consequences of biodiversity loss: the evolution of a paradigm. Ecology 83:1537-1552

Nakagawa S, Schielzeth H (2013) A general and simple method for obtaining $R^{2}$ from generalized linear mixed-effects models. Methods Ecol Evol 4:133-142 doi:10.1111/j.2041-210x.2012.00261.x

Nordin A, Schmidt IK, Shaver GR (2004) Nitrogen uptake by arctic soil microbes and plants in relation to soil nitrogen supply. Ecology 85:955-962

Pasari JR, Levi T, Zavaleta ES, Tilman D (2013) Several scales of biodiversity affect ecosystem multifunctionality. Proc Natl Acad Sci USA 110:10219-10222

Pereira HM, Navarro LM, Martins IS (2012) Global biodiversity change: the bad, the good, and the unknown. Annu Rev Env Resour 37:25-50

Raich JW, Schlesinger WH (1992) The global carbon dioxide flux in soil respiration and its relationship to vegetation and climate. Tellus B 44:81-99

Reid WV, Watson RT, Rosswall T, Steiner A, Töpfer K, Arico S, Bridgewater P (2005) Millennium ecosystem assessment: ecosystems and human well being- synthesis report.

Roesch LFW, Fulthorpe RR, Riva A, Casella G, Hadwin AKM, Kent AD, Daroub SH, Camargo FAO, Farmerie WG, Triplett EW (2007) Pyrosequencing enumerates and contrasts soil microbial diversity. ISME J 1:283-290

Scherer-Lorenzen M, Palmborg C, Prinz A, Schulze ED (2003) The role of plant diversity and composition for nitrate leaching in grasslands Ecology 84:1539-1552

Schmidt IK, Michelsen A, Jonasson S (1997) Effects of labile soil carbon on nutrient partitioning between an arctic graminoid and microbes. Oecologia 112:557-565

Seidel D, Leuschner C, Scherber C, Beyer F, Wommelsdorf T, Cashman MJ, Fehrmann L (2013) The relationship between tree species richness, canopy space exploration and productivity in a temperate broad-leaf mixed forest. Forest Ecol Manag 310:366-374

Shan Y, Chen D, Guan X, Zheng S, Chen H, Wang M, Bai Y (2011) Seasonally dependent impacts of grazing on soil nitrogen mineralization and linkages to ecosystem functioning in Inner Mongolia grassland. Soil Biol Biochem 43:1943-1954

Valencia E, Maestre FT, Le BPY, Quero JL, Tamme R, Börger L, Garcíagómez M, Gross N (2015) Functional diversity enhances the resistance of ecosystem multifunctionality to aridity in Mediterranean drylands. New Phytol 206:660-671

van der Heijden MGA, Bardgett RD, van Straalen NM (2008) The unseen majority: soil microbes as drivers of plant diversity and productivity in terrestrial ecosystems. Ecol Lett 11:296-310

Wagg C, Bender SF, Widmer F, van der Heijden MGA (2014) Soil biodiversity and soil community composition determine ecosystem multifunctionality. Proc Natl Acad Sci USA 111:5266-5270

Walter J, Hein R, Beierkuhnlein C, Hammerl V, Jentsch A, Schädler M, Schuerings J, Kreyling J (2013) Combined effects of multifactor climate change and land-use on decomposition in temperate grassland. Soil Biol Biochem 60:10-18

Wan Z, Yang J, Gu R, Liang Y, Yan Y, Gao Q, Yang J (2016) Influence of different mowing systems on community characteristics and the compensatory growth of important species of the Stipa grandis steppe in Inner Mongolia. Sustainability 8:1121-1131 
Wardle DA, Bardgett RD, Klironomos JN, Setälä H, Wh VDP, Wall DH (2004) Ecological linkages between aboveground and belowground biota. Science 304:1629-1633

Yang Y, Wu L, Lin Q, Yuan M, Xu D, Yu H, Hu Y, Duan J, Li X, He Z (2013) Responses of the functional structure of soil microbial community to livestock grazing in the Tibetan alpine grassland. Global Change Biol 19:637-648

Zavaleta ES, Pasari JR, Hulvey KB, Tilman GD (2010) Sustaining multiple ecosystem functions in grassland communities requires higher biodiversity. Proc Natl Acad Sci USA 107:1443-1446

Zou YL, Niu DC, Fu H, Zhang YC, Wan CG (2015) Moderate grazing promotes ecosystem carbon sequestration in an Alpine meadow on the Qinghai-Tibetan Plateau. J Anim Plant Sci 25:165-171

(1)

(1)

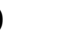


644 Table 1 Summary of the linear mixed-effects model for the effects of plant and soil

645 biodiversity on grassland multifunctionality

\begin{tabular}{lcccccc}
\hline Source & $\mathrm{n}$ & Estimate & $\mathrm{SE}$ & $\mathrm{t}$-value & $P_{r}(>|\mathrm{t}|)$ & $\mathrm{VIF}$ \\
\hline Plant diversity & 12 & 1.2987 & 0.4030 & 3.222 & 0.0061 & 1.124 \\
Bacterial diversity & 12 & -0.3542 & 0.6806 & -0.520 & 0.3086 & 1.015 \\
Fungal diversity & 11 & -0.0944 & 0.2258 & -0.418 & 0.3442 & 1.115 \\
Marginal $R^{2}=0.625$ & & & & & & \\
\hline
\end{tabular}

SE, standard errors; VIF, variance inflation factor. VIF is used to check the collinearity between explanatory variables in multiple linear regressions; a collinearity problem occurs when the value of VIF exceeds 10 .

646

647

648

649

650

651

652

653

654

655

656

657

658 
Fig. 1 The effects of different management regimes (E, enclosure; G1, all 660 growing-season grazing; G2, spring \& summer grazing; $\mathrm{M}$, mowing) on the 661 multifunctionality index. Different lowercase letters indicate significant differences 662 between means at $P<0.05(\mathrm{n}=3)$, after using LSD test for post hoc comparisons. Error 663 bars represent $\pm 1 \mathrm{SE}$

664

Fig. 2 The effects of different management regimes (E, enclosure; G1, all 666 growing-season grazing; G2, spring \& summer grazing; M, mowing) on the different 667 functional indices related to the $\mathrm{C}, \mathrm{N}, \mathrm{P}$ cycles and plant productivity. Different 668 lowercase letters indicate significant differences between means at $P<0.05(\mathrm{n}=3)$, 669 after using LSD tests for post hoc comparisons. Error bars represent $\pm 1 \mathrm{SE}$ Fig. 3 Relationships between grassland multifunctionality and the diversity of plant 672 (a), soil bacteria (b), and soil fungi (c). The fitted lines are from general linear 673 regressions, with only significant fitted lines $(P<0.05)$ shown. Shaded areas show $95 \%$ confidence interval of the fit

Fig. 4 Relationships between C, N, P cycling and Productivity indices and the 677 diversity of plant (a-d) and soil bacterial (e-h) communities. The fitted lines are from general linear regressions, with only significant fitted lines $(P<0.05)$ shown. Shaded areas show $95 \%$ confidence interval of the fit 


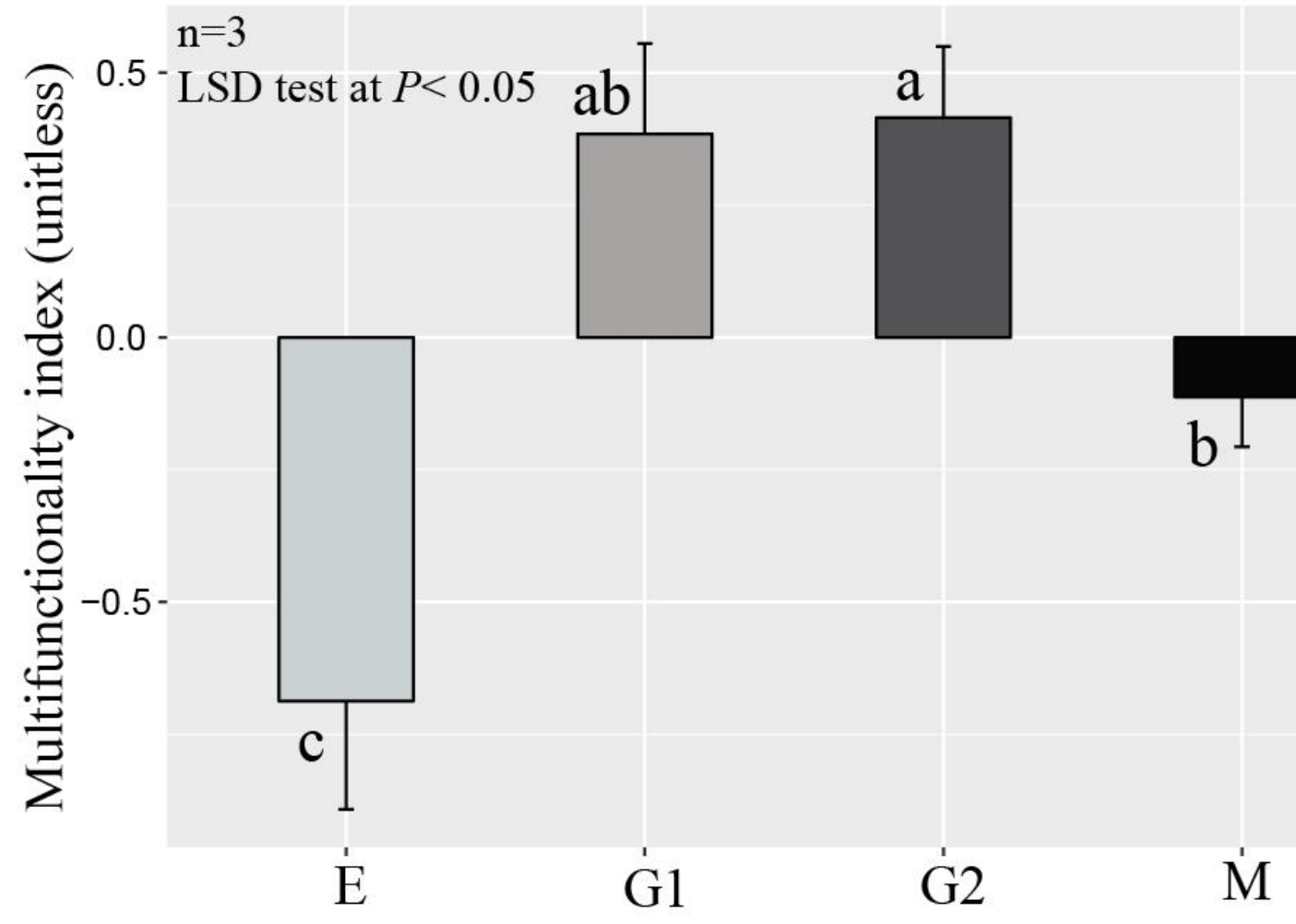

$681 \quad$ Fig. 1

682

683

684

685

686

687

688

689

690

691

692 

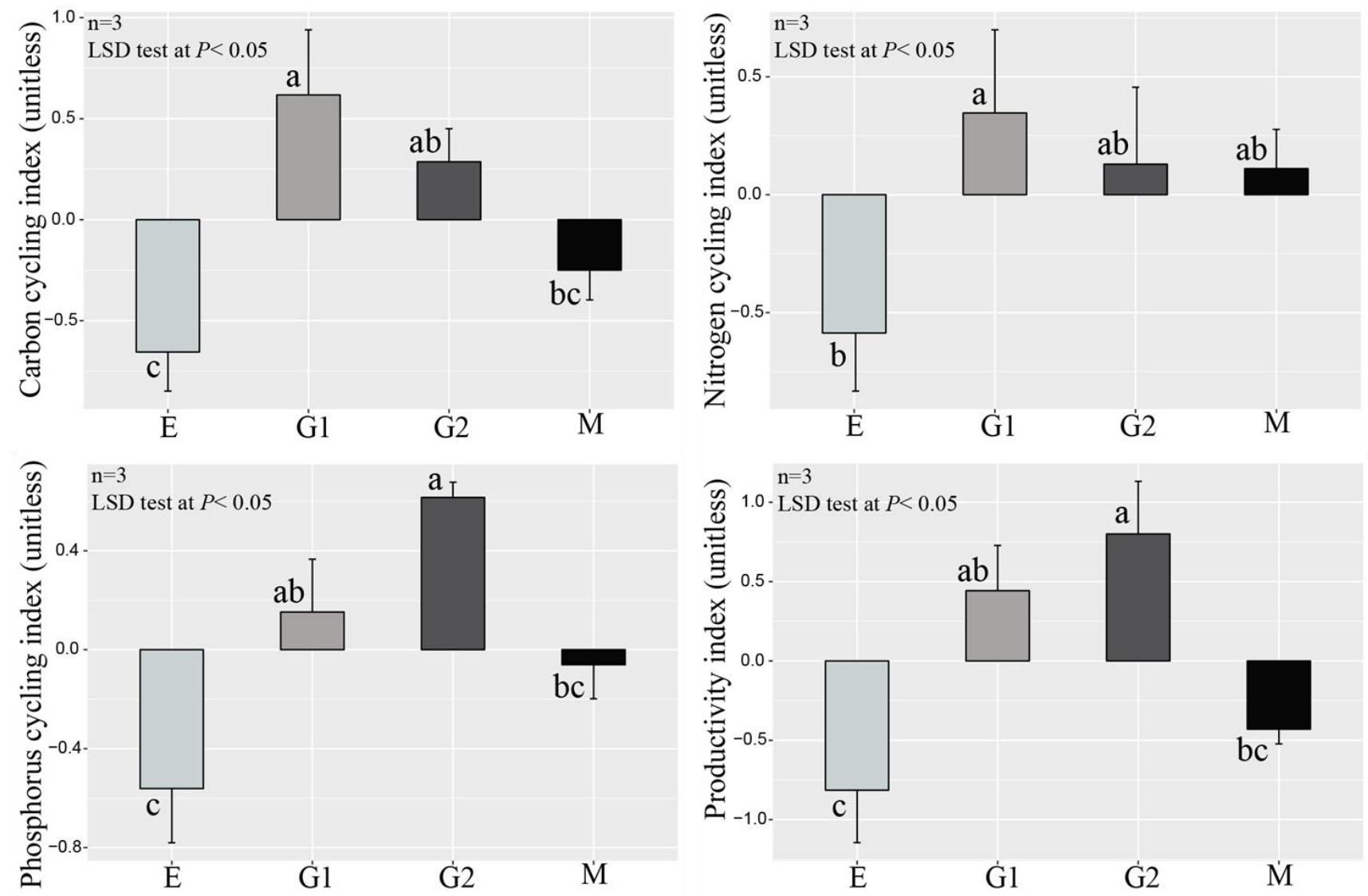

$694 \quad$ Fig. 2

695

696

697

698

699

700

701

702 

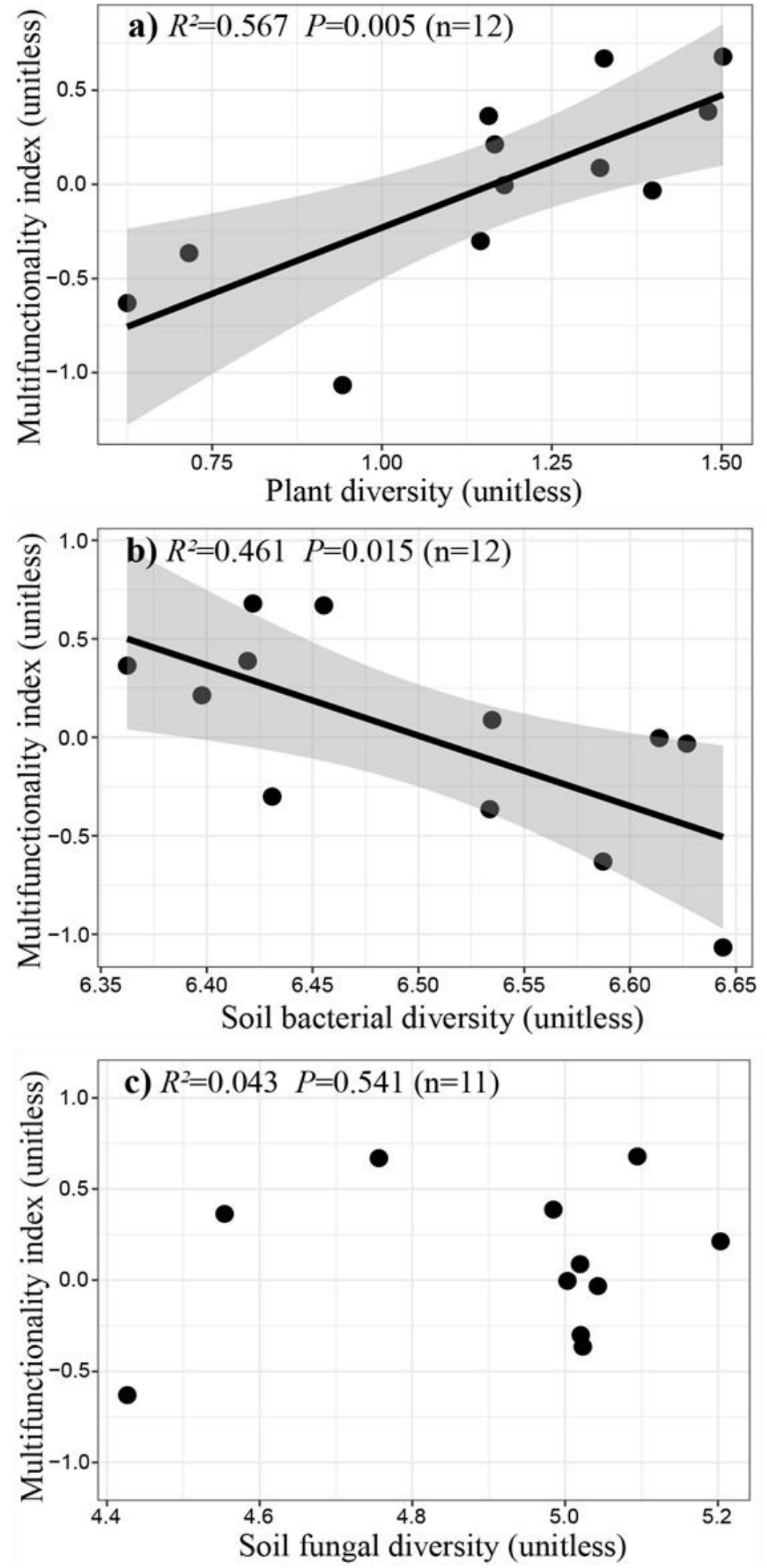

Fig. 3 

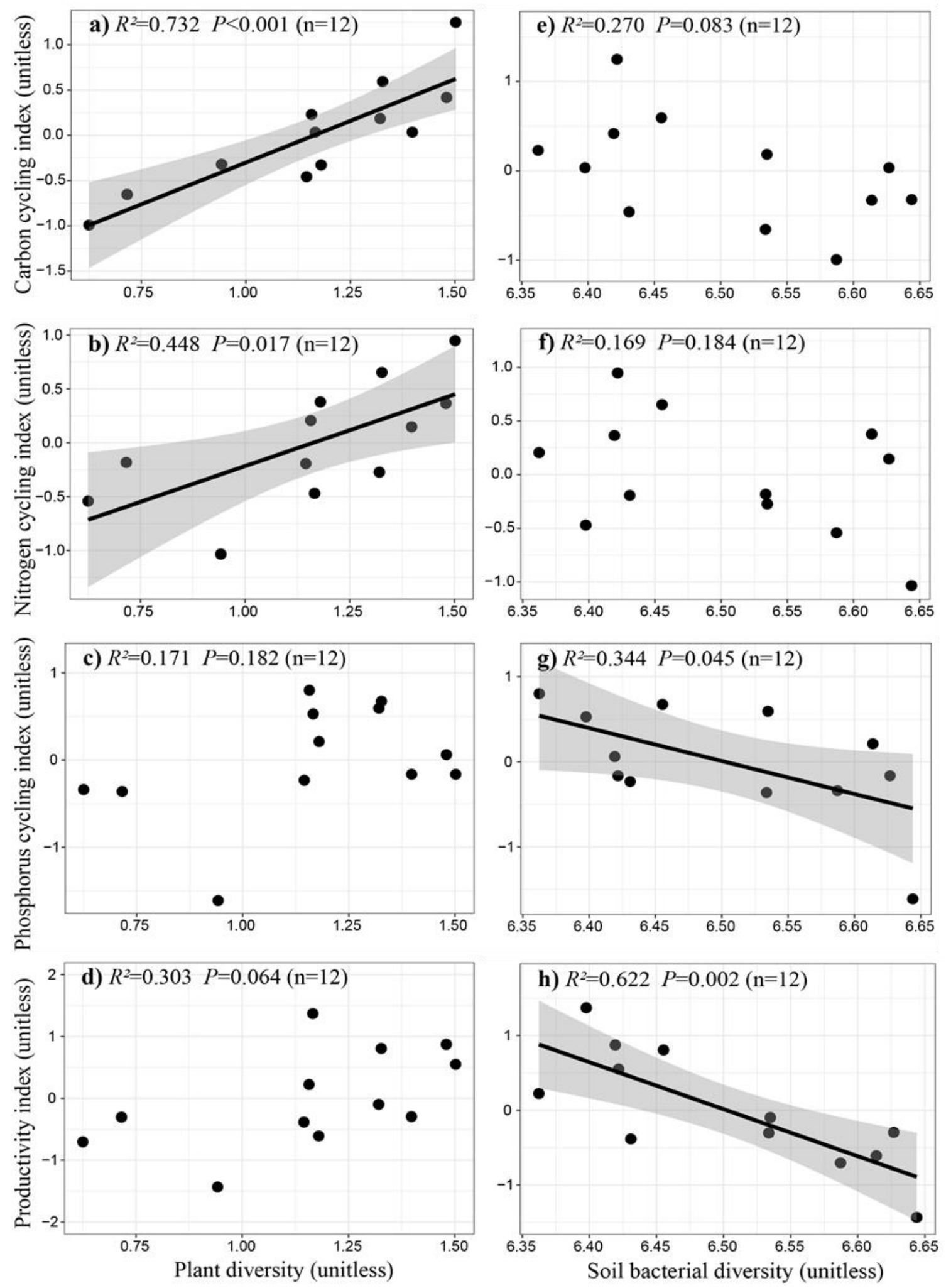

Fig. 4 